\title{
Rough Fescue (Festuca scabrella Torr.) in Washington
}

\section{HARMON S. HODGKINSON AND ALFRED E. YOUNG}

Highlight: In Washington, rough fescue occurs primarily north of the $47^{\circ}$ latitude and east of the Cascade Mountains. There are two large, well-represented areas. Other locations are represented by small areas, some containing only scattered plants. Rough fescue is very palatable and should be managed as the key species when it makes up more than $15 \%$ of the total plant composition. To maintain or improve good stands, no more than $50 \%$ of the annual current year's growth should be removed.

In Washington, where rough fescue (Festuca scabrella Torr $^{1}$.) occurs, it produces abundant, palatable forage for livestock and big game and has an extensive fibrous root system for holding soil. Rough fescue occurs only in certain locations, on the loamy and shallow range sites. When it makes up more than $15 \%$ of the total plant composition, it may become the key species for management.

Rough fescue is an erect, tufted, perennial bunchgrass with stalks (culms) 1 to 4 feet high and basal leaves usually 4 to 12 inches long (U.S. Dep. Agr., 1937). In eastern Washington, annual leaf growth has been measured up to 22 inches long on healthy plants. Although rough fescue usually grows as large bunches often measuring 12 to 14 inches in diameter, Johnston and Cosby (1966) report rhizomatous (creeping-rooted) forms in British Columbia, the Prairie Provinces, Montana, North Dakota, and Newfoundland.

This plant is commonly called "rough fescue" because of its rough (scabrous)

The senior author is a range conservationist with the Soil Conservation Service, U. S. Department of Agriculture, Okanogan, Washington. Alfred Young was formerly a range conservationist at the same location, but has since retired; his present address is Chattaroy, Washington.

Manuscript received April 14, 1972.

\footnotetext{
${ }^{1}$ Botanical names of species are according to Hitchcock et al. (1969).
}

leaves and stalks. It has also been called "buffalo bunchgrass." Rough fescue was the main winter forage for the buffalo of the northern Great Plains. The buffalo summered on the open mixed prairie but moved with the onset of winter to hilly, partially wooded country now classed as the fescue grassland (Johnston and MacDonald, 1967).

Rough fescue is a widely distributed species occurring in Canada from British
Columbia to Newfoundland; from eastern Washington and eastern Oregon to North Dakota; and in Michigan, Wyoming, and Colorado (U.S. Dep. Agr., 1937; Hitchcock et al., 1969).

To the north of Washington, in British Columbia, McLean and Marchand (1968) reported rough fescue as a dominant to abundant species in the floristic composition of the bluebunch wheatgrass (Agropyron spicatum)-rough fescue site and an abundant species in the ponderosa pine (Pinus ponderosa) site.

In Montana, the range of rough fescue coincides with the mountainous areas of the central and northern parts of the state (Stickney, 1961).

Daubenmire (1970) found rough

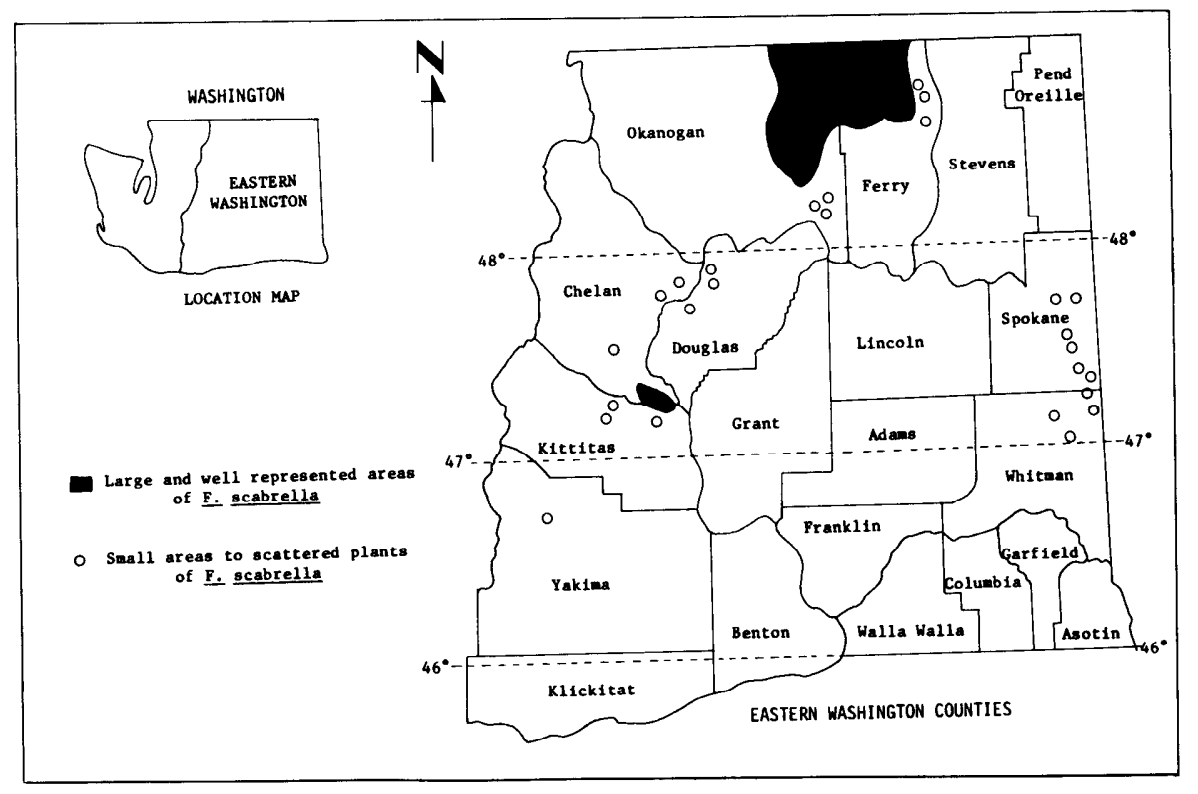

Fig. 1. Approximate locations of rough fescue (Festuca scabrella) in the State of Washington. 


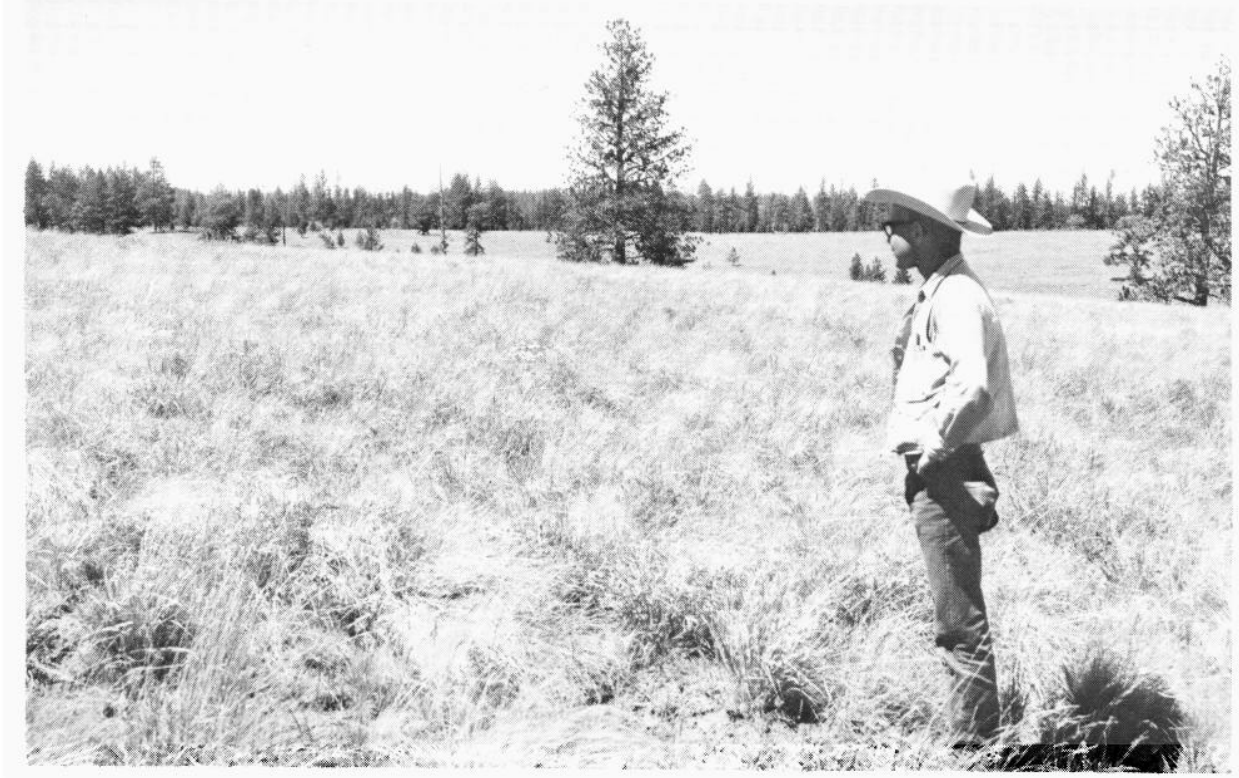

Fig. 2. Rough fescue is the dominant grass in this high elevation mountain grassland area. It also extends into the ponderosa pine-Douglas fir in background.

fescue associated in the Festuca idahoensis-Eriogonum heracleoides, and Festuca idahoensis-Symphoricarpos albus habitat types while studying the steppe vegetation of Washington. To some extent, it is also associated in the Pinus ponderosa-Symphoricarpos albus habitat type (Daubenmire, 1968).

In Washington, rough fescue occurs in several areas primarily north of the $47^{\circ}$ latitude and east of the Cascade Mountains (Fig. 1). Two large and wellrepresented areas of rough fescue are in northeastern Okanogan County and northwestern Ferry County. A third is in southeastern Chelan County. Small areas, some with only scattered plants, are in Whitman, Spokane, Ferry, Okanogan, Chelan, Douglas, Kittitas, and Yakima counties.

In Okanogan and Ferry counties, rough fescue occurs on the loamy and shallow range sites. The soils are black, medium or moderately coarse textured, deep, well drained, occurring in glacial till and outwash materials. Ash content or pyroclastic material is high. Soils are classified as Mollic Vitrandepts, frigid, or Typic Haploxerolls, frigid. The major soil series names are Molson, Chesaw, Hunters, and Koepke.

Elevations range from 2,000 to 6,000 $\mathrm{ft}$. Precipitation ranges from 14 to 22 inches per year. Slopes are 0 to $65 \%$. Exposures are generally cool and moist. The growing season is cool and short.

Rough fescue is associated with bluebunch wheatgrass, Idaho fescue (Festuca idahoensis), bluegrasses (Poa sp.), needlegrasses (Stipa sp.), yarrow (Achillea of $7.5,5.8,4.9,1.8$, and 0.6 with 0,20 , 50,70 , and $90 \%$ utilization, respectively. The forage production yield decreased as grazing became heavier, and plant litter largely disappeared under the very heavy $(90 \%)$ grazing. They also found that under the very heavy grazing, the character of the soil changed. It became drier, and lighter in color and had higher soil temperatures. Moderate (50\%) grazing maintained a high proportion of plants, encouraged early plant growth and, with the presence of litter and mulch, increased available moisture absorption. In another study, Johnston and MacDonald (1967) found close grazing in the winter did not kill plants or appreciably reduce their summer vigor.

This research confirms observations in Washington. In Ferry County, rough fescue, managed in a deferred-rotation grazing system and with moderate grazing, showed an increase in size and vigor. Encouraging vigorous healthy plants in this way will result in higher usable forage yields. In northeastern Okanogan County, an area ungrazed for several years and dominantly rough fescue yielded 2,400 pounds air dry forage per acre.

Ranchers and range managers in Washington should recognize rough fescue, its growth characteristics and requiremenis and then manage to maintain or increase its forage yielding ability for meat production and soil and water conservation.

\section{Literature Cited}

Rough fescue is very palatable and relished by livestock and big game throughout the grazing season. It should be managed as the key species when it produces more than $15 \%$ of the total forage yield in a grazing pasture. A key species usually has a relatively high grazing preference and generally provides more than $15 \%$ of the readily available forage within a given area.

Locationed at higher elevations, rough fescue is grazed during the summer season. Overgrazing during this time can greatly damage the plant, and 2 to 3 years of heavy use can remove the species from the pasture. This is because of its erect growth habit enabling livestock to graze close and remove most of the photosynthetic tissue. For this reason, it has been virtually eliminated from many ranges where it once was important.

Johnston et al. (1971) found at Stavely, Alberta, the percent basal area of rough fescue reflected grazing history. They report after 17 years of continuous summer (May 15 to November 15) grazing, rough fescue had a basal area percent
Daubenmire, R., and Jean B. Daubenmire. 1968. Forest vegetation of eastern Washington and northern Idaho. Wash. Agr. Exp. Sta. Tech. Bull. 60. 104 p.

Daubenmire, R. 1970. Steppe vegetation of Washington, Wash. Agr. Exp. Sta. Tech. Bull. 62. $131 \mathrm{p}$.

Hitchcock, C. Leo, Arthur Conquist, Marion Ownbey, and J. W. Thompson. 1969. Vascular plants of the Pacific Northwest. Univ. of Wash. Press, Seattle. Parts 1-5.

Johnston, A., and Hugh E. Cosby. 1966. Rhizomatous form of Festuca scabrella. Can. J. Plant Sci. 46:211-212.

Johnston, A., and M. D. MacDonald. 1967. Floral initiation and seed production in Festuca scabrella. Can. J. Plant Sci. 47:577-583.

Johnston, A., J. F. Dormaar, and S. Smolick. 1971. Long-term grazing effects on fescue grassland soils. J. Range Management. 24:185-188.

McLean, A., and L. Marchand. 1968. Grassland ranges in the southern interior of British Columbia. Canada Dep. Agr. Pub. 1319. 28 p.

Stickney, P. F. 1961. Range of rough fescue (Festuca scabrella Torr.) in Montana. Proc. Montana Acad. Sci. 20:12-17.

U.S. Dep. Agr. 1937. Range Plant Handbook. Forest Service, Washington, D.C. 